\title{
Assessment of Some Water Quality Characteristics and Bacterial Contamination in Water, Sediments and Some Fish species of El-Manzala Lake
}

\author{
Eman Attia Abdel-Samie Abdel-Hamid \\ Limnology Department, Central Laboratory for Aquaculture Research, \\ Abbassa, Abou-Hammad, Sharkia, Egypt \\ E. mail: e_abdelhamid2014@yahoo.com
}

\section{ABSTRACT}

Water plays a vital role in the proper functioning of earth ecosystem and also essential for fish life. In autumn season, 2016, three different regions from El-Manzla Lake (El-Boughaz, Domiette and El-Ganka) were selected to determine their water quality and bacterial contaminations. Water, sediment and fish samples were collected from four different sites of each region. The selected regions are exposing to direct and indirect industrial, municipal wastewater and agricultural drainage disposals. The results showed that El-Ganka region had significantly $(\mathrm{P}<0.05)$ highest nitrogenous compounds $\left(\mathrm{NH}_{3}-\mathrm{N}, \mathrm{NO}_{2} \& \mathrm{NO}_{3}\right)$, total nitrogen, total and available phosphorus and Chlorophyll a followed by Domiette and then El-Boughaz. While had the significantly $(\mathrm{P}<0.05)$ lowest $\mathrm{pH}$ and secchi disk (SD). Water exchange between the Mediterranean Sea and the lake led to significant increase values $(\mathrm{P}<0.05)$ in its salinity and conductivity at the El-Boughaz region. Also, some bacteriological characteristics (Bacterial count, coliform and some pathogens) in water, sediment and some fish organs (skin, muscle \& gills) of Oreochromis niloticus and Clarias gariepinus were determined.

Total bacterial count, coliform group, fecal coliform and Vibrio cholera recoded higher values in sediment than in water. Total bacterial count and coliform group in the muscle of the two investigated fish species had lower values than skin and gills, while fecal coliform and vibrio were not detected. Gills recorded higher values than those 
in the skin. Muscles of Clarias gariepinus recorded higher levels in all bacterial parameters than the Oreochromis niloticus in contrast the skin and gills.

On base of the present study, it could be concluded that Manzala' lake water resources need more attention to be protected for aquaculture purposes and sustainable development through the detection of aquatic biological agents and possible control of water quality.

Key words: water quality, sediment, fish, bacterial contamination, Nile tilapia, Catfish.

\section{Introduction}

In Egypt, Lakes are very important part of the aquatic ecosystem, which is considered as one of the most important sources of inland fishery in Egypt. It is the largest lake of the four brackish coastal lakes fringing the Nile Delta. It lies between $31045^{\prime}, 32015^{\prime} \mathrm{E}$ and $31000,31035 \mathrm{~N}$. Lake. It is located in the north-eastern edge of the Nile delta and suffering from different pollutants. It is considered as one of the most important sources of inland fishery in Egypt where it is estimated to yield about $38.02 \%$ of the northern Nile Delta lakes and is considered as the second major source of fish after Lake Burollus. Importance of the lake fishery returns to two main targets as a source of animal protein for human consumption and a source of employment (El-Bokhty, 2010).

The lake is connected to the Mediterranean Sea via three outlets, permitting water and biota exchange between the lake and the sea. These outlets are El-Gamil, El-Boughdady and the new El-Gamil (Elewa et al., 2007). It has been shrinked in size; the rate of shrinking of the total area between 1922 and 1995 was estimated, being 5.22 $\mathrm{km}^{2} /$ year. The greater losses of the lake areas were detectable along the western and southern borders of the lake (Frihy et al., 1998).

Fishes are considered as one of the most significant bio-monitors in an aquatic system for the estimation of water pollutants concentrations (Begum et al., 2005). Lake Manzala faces many challenges that will lead to serious changes in its water quality and fish production. A remarkable decline (34.5\%) of the Manzala lagoon 
surface area has been estimated. These changes have been attributed mainly to the control of River Nile flooding and land use changes resulting from anthropogenic activities (El-Asmar and Hereher, 2011). Lake Manzala has gradually transformed, with time, from a brackish environment to eutrophic fresh water in response to increased fresh water inputs, nutrient loading associated with agricultural land reclamation processes and due to the urban waste disposal (Bishai and Yossef, 1977).

Soil biological investigations give information on the impact of environmental conditions on the metabolic activity of soil (Margesin and Schinner, 2005). Fecal pollution from warm-blooded animals including humans poses public health risks due to possible exposure to a wide array of pathogenic bacteria, viruses and protozoa (Baker $\&$ Herson, 1999 and Fong et al., 2005). Fecal indicator bacteria such as coliforms, Escherichia coli and enterococci have long been used by the water quality monitoring authorities to detect fecal pollution and the presence of potential pathogenic microorganisms.

Bacteria of the genus vibrio are indigenous in marine and estuarine aquatic ecosystems in which shrimp occur naturally or are farmed (Ruangpan and Kitao, 1991). Pathogens in the pond organic sludge have the potential to cause disease outbreak and impaired fish production. The presence of pathogenic bacteria generates concerns not only for shrimp health but also that of consumers.

Nutrient cycles in Egyptian lakes are largely influenced by metabolic processes localized in the surface layers of water and sediments. Lake Manzala has an important impact on fish production due to its water content zone variability, from marine to fresh, suitable conditions for varieties of aquaculture.

Lake Manzala attracts attention of many scientists because of its important economic aspects. Unfortunately, the lake suffers from high load of anthropogenic pollutants (Abbassy et al., 2003). Several investigations have been carried out concerning its ecosystem. These studies aimed to evaluate some water quality variables in three regions and its impacts on bacterial contaminations of water, sediments and fish organs (Skin, Gills \& Muscles) of O. niloticus and C. gariepinus. 


\section{MATERIALS AND METHODS}

\section{Study Area}

During autumn season, 2016, three different regions at lake ElManzala were chosen (Fig. 1) to evaluate the water quality and bacterial contaminations of water, sediments and some fish organs (Skin, Gills \& Muscles) of O. niloticus and C. gariepinus.

These regions were:

El-Boughaz region: represented by the sites 1, 2, 3 and 4.

El-Ganka region: represented by the sites 5, 6, 8 and 9 .

Domiette region: represented by the sites $12,13,14$ and 15 .

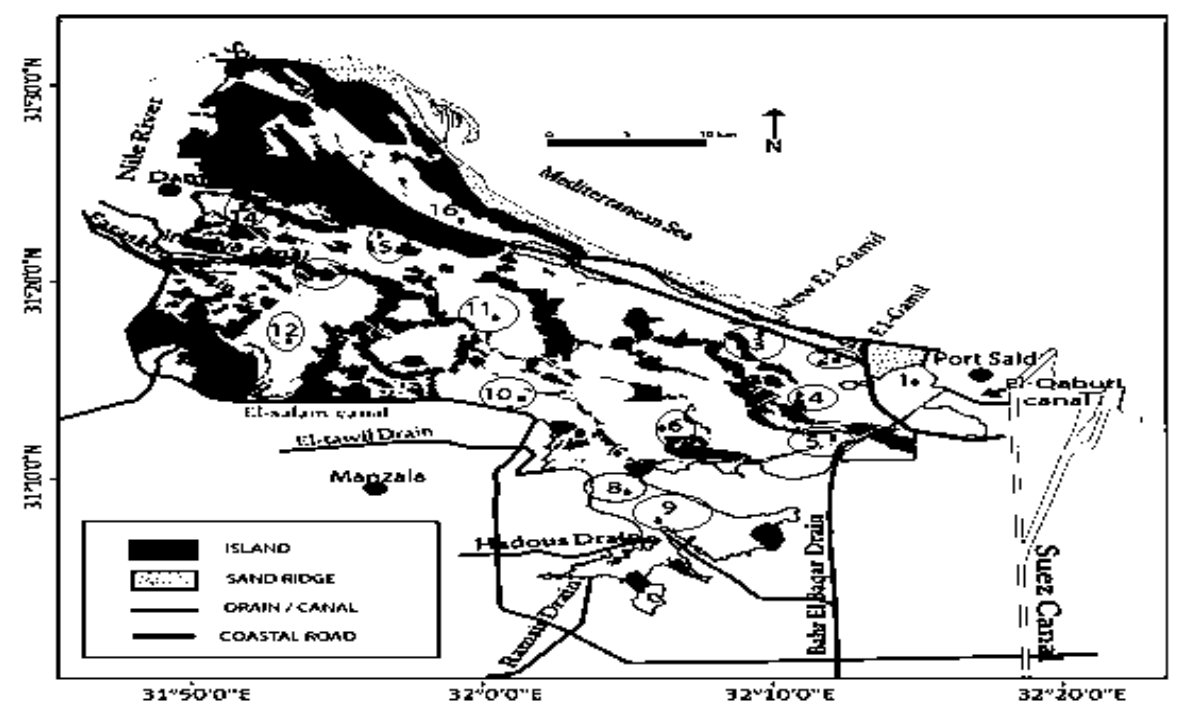

Fig. 1 Manzala Lake maps clear different locations and main drain canals.

\section{Field Measurements and Sample Collection}

Water temperature and dissolved oxygen (DO) values were measured by using a digital oxygen meter (AQUALYTIC, OX 24). Water $\mathrm{pH}$ values were measured with a $\mathrm{pH}$ meter (Model 25, Fisher Scientific). Salinity (mg/l) was determined using salinity, conductivity meter (model YSI Environmental, EC 300).

According to APHA (1992), water samples were collected in $500 \mathrm{ml}$ sterile bottles at $0-20 \mathrm{~cm}$ below the water surface. Sediment samples 
were taken at $0-5 \mathrm{~cm}$ depth of the soil from the selected regions in $250 \mathrm{ml}$ sterile plastic bags. Fish samples were obtained from fisherman and packed in sterile bags. All samples were brought to the laboratory in an ice chest, and processed within $4 \mathrm{hrs}$ of collection. Laboratory analyses:

The total hardness, total alkalinity, total ammonia $\left(\mathrm{NH}_{3}+\mathrm{NH}_{4}{ }^{+}\right)$ and then $\mathrm{NH}_{3}$ was calculated, nitrate $\left(\mathrm{NO}_{3}\right)$, nitrite $\left(\mathrm{NO}_{2}\right)$, orthophosphate $\left(\mathrm{PO}_{4}\right)$ Total Dissolved Solids (TDS), Total Suspended Solid (TSS) $\{\mathrm{mg} / \mathrm{l}\}$, and Chlorophyll "a" $\{\mu \mathrm{g} / \mathrm{l}\}$ were measured by the methods described in Boyd and Tucker (1992).

\section{Bacterial Examinations:}

Bacteria from the water, sediment and fish were isolated using the spread plate technique. One milliliter of the water sample was serially diluted in sterile peptone water and plated. One gram of the sediment was homogenized in $9 \mathrm{ml}$ sterile water, and a serial 10-fold dilution up to $10^{5}$ was prepared in sterile peptone water and plated. Skin, muscle and gills contents of fishes were taken aseptically, I cm and 1 $\mathrm{g}$ of this was homogenized in $9 \mathrm{ml}$ sterile peptone water, the homogenized samples were then diluted using 10- fold serial dilution up to $10^{5}$ in sterile peptone water . Total bacterial count, coliform group, fecal coliform (Escherichia coli) and vibrio cholera were estimated on plate count agar, Mackonky agar (Oxoid) and thiosulphate citrate bill sucrose agar (TCBSA, Biolife), respectively according to APHA (1995). Three Petri-dishes from dilutions were incubated for total bacterial count, coliform and Vibrio cholera at 37 ${ }^{\circ} \mathrm{C}$ for 24 hours. Fecal coliform incubated at $44.5 \pm 2{ }^{\circ} \mathrm{C}$ for $24-48 \mathrm{hrs}$.

\section{Statistical Analysis}

One-way ANOVA and Duncan multiple range test were used to evaluate the significant differences among different investigated parameters means at different regions. Probability at level of 0.05 or less $(\mathrm{P} \leq 0.05)$ was considered significant (Bailey, 1981). Standard errors were also estimated.

\section{Results and Discussion}

Water is one of the most essential constituents of the human environment. The resource generates development in socio- 
economical issues crucial to the society in general and more specifically for industries, agricultural activities and for the public use. Water quality refers to the physical, chemical and biological characteristics of water in relation to the existence of life and especially human activity. The quality of water is predetermined by the intended uses and each of these uses affects, more or less, its quality.

Data in table (1) illustrated the physico-chemical parameters in selected regions of El- Manzala Lake in autumn season, 2016. Water temperatures in the selected regions were not significantly $(\mathrm{P} \leq 0.05)$ different. Its values in the different regions were ranged from $30.50 \pm 0.50$ to $30.7 \pm 0.20^{\circ} \mathrm{C}$ and were closely followed air temperature and this range of temperature is suitable for survival and growth of warm water fish. Temperature is a critical control parameter in the aquatic systems and it is a key parameter which influences the physical, chemical and biological transformations in the aquatic environment (Delince, 1992 and Tayel et al., 2008).

Water $\mathrm{pH}$ is one of the most important chemical parameters. Changes in the ionic strength and $\mathrm{pH}$ play an important role in the solubility and precipitation of metals. Mixing of drainage water (slightly alkaline) with sea water (more alkaline) in the lake cause changes in phase distribution of some metals and organic matter. The $\mathrm{pH}$ of natural water affects biological and chemical reactions, controls the solubility of metal ions, and affects natural aquatic life (Tayel, 2003). High $\mathrm{pH}$ values were recorded at Domiette while low values were in El Ganka. These results are in consistence with Fredrickson et al. (2004) who stated that the range at which fish has optimum growth is at temperature between 24 and $35^{\circ} \mathrm{C}$ and $\mathrm{pH}$ range between 6.5 and 9.0. El-Badry (2016) recorded that the $\mathrm{pH}$ values near the drains (El-Gammaliah drain, El-Serw drain, Inaniya drain and Bahr El-Bakar drain) are lower than the other regions of the lake. This could be explained on the basis of the fermentation of the organic matter and the release of hydrogen sulfide and methane gases which lead to lower $\mathrm{pH}$ values.

The lowest $\mathrm{pH}$ values appeared in locations subjected to the outfall of sewage wastewater and drainage water near the inlet of Bahr ElBakar drain, Ramsis and Hadous drain in El Kabouty Port. These 
results are in agreement with those obtained by Koussa (2000) and Moussa (2004) in Maruit and Borulls Lakes, respectively. Also, Shaker (2006) reported that the changes of $\mathrm{pH}$ vales may be related to the density of phytoplankton standing crop and dissolved oxygen as a result of photosynthetic activity. Similar results were observed by Koussa (2000) and Moussa (2004).

The increased $\mathrm{pH}$ values of the lake water can be attributed to the consumption of $\mathrm{CO}_{2}$ with high rates through the process of photosynthesis undertaken by the intensive masses of macrophytes in the lake. This may lead to the conclusion that the discharge of sewage wastewater and drainage water to the lake contributes in decreasing the $\mathrm{pH}$ of the lake water as a result of mixing specially at the area of the lake near to the outlet of Bahr El Bakar, Ramsis and Hadous drains where high rates of drainage water discharge. The $\mathrm{pH}$ safe range for fish survival is between 5 and 9 , while optimum productivity can be obtained at 6.5 till 8.5 . So, the $\mathrm{pH}$ of fish farm and lakes in Egypt lies on the alkaline side and is suitable for inhabiting aquatic organisms (Shaker and Abdel Aal, 2006).

The highest transparency values were at El-Boughaz and Domiette and then at El-Ganka $(28.50 \pm 2.00,20.20 \pm 1.50$ and $11.50 \pm 0.50 \mathrm{Cm}$, respectively). On the other hand, the highest total suspended solids (TSS) was at El-Ganka $(7.85 \pm 0.06 \mathrm{mg} / \mathrm{l})$ followed by Domiette $(5.75 \pm 0.06 \mathrm{mg} / \mathrm{l})$ and then El-Boughaz $(3.77 \pm 0.17 \mathrm{mg} / \mathrm{l})$. The highest total dissolved solid (TDS) values were at El-Boughaz $(4.85 \pm 0.21$ $\mathrm{mg} / \mathrm{l})$ followed by El-Ganka $(3.22 \pm 0.06 \mathrm{mg} / \mathrm{l})$ and then Domiette $(2.46 \pm 0.02 \mathrm{mg} / \mathrm{l})$. These results agree with those of El-Badry (2016), who found that the highest value of total dissolved salts was recorded in the eastern portion of the lake near to El-Boughaz opening affected by sea water, the high rates of evaporation, in addition to wind action. Total Dissolved Solid (TDS) is a water quality parameter defining the concentration of dissolved organic and inorganic chemicals in water. It is used to evaluate the quality of freshwater systems. TDS is an indication of the potential buffering capacity of water and water hardness. TDS concentrations are equal to the sum of positively charged ions (cations) and negatively charged ions (anions) in the water (DRI, 2010) 
Dissolved oxygen (DO) is a measure of the amount of oxygen freely available in water. The concentration of dissolved oxygen gives information on the possibilities for flora and fauna living in the water system. The concentration of DO is controlled by consumption by aerobic organisms. The DO for surface water ranges from 0 in extremely poor water conditions to a high of $15 \mathrm{mg} / \mathrm{l}$ in very healthy water at $25^{\circ} \mathrm{C}$ (EPA, 1999).

The highest DO mean values were at El-Boughaz $(6.80 \pm 0.10 \mathrm{mg} / \mathrm{l})$ and Domiette $(5.10 \pm 0.20 \mathrm{mg} / \mathrm{l})$. On the other hand, the lowest values were recorded in El Ganka $(2.20 \pm 0.20 \mathrm{mg} / \mathrm{l})$. This is may be due to the increase influence and flow of the sewage water drain in El Ganka and particularly associated with polluted drains flowing into the lake. The present results agree with those of Ali (2008) who found that the water of Lake Manzala is well oxygenated during different time intervals except the inlet of Bahr El-Bakar region which suffered from complete depletion of dissolved oxygen as a result of decomposition of organic matter and materials consumed the dissolved oxygen. Also, Elewa et al. (2007) found that the values of DO fluctuated between 3.0 and $8.4 \mathrm{mg} / 1$ at the same areas. Besides that, the increasing flow of drainage water increases the productivity of floating algae in the lake which consume oxygen and decrease its levels.

Concern to total alkalinity, there were no significant differences among different selected regions which ranged from $250 \pm 5.78$ to $261.33 \pm 1.86 \mathrm{mg} / \mathrm{l}$. These results were in agreement with that obtained by Fathi et al. (2001), who cited that the total alkalinity of Lake Manzala water ranged between 200 and 300 mg/l.

The highest total hardness values were recorded at El-Boughaz $(2150.00 \pm 16.68 \mathrm{mg} / \mathrm{l})$ whereas the lowest one was at Domiette $(550.00 \pm 20.00 \mathrm{mg} / \mathrm{l})$, respectively. Wetzel, $(\mathbf{1 9 8 3})$ recorded the same results and attributed it to the relative variations in magnesium distribution pattern except at El-Boughaz area, which was mainly attributed to the high solubility characteristics of its salts, which keep a homogenous distribution and mass balance for magnesium. Salinity is a major driving factor that affects the density and growth of aquatic populations (Jamabo, 2008). The highest value was at El-Boughaz $(12.5 \pm 1.1 \mathrm{mg} / \mathrm{l})$ while the lowest was recorded at Domiette $(2.6 \pm 0.3$ $\mathrm{mg} / \mathrm{l})$. This is may be due to that El-Boughaz considers nearest site to 
the Mediterranean Sea. Electrical conductivity recorded the same trend of salinity.

Table 1: Average vales (Means \pm SE) of some Physico-chemical parameters of water at three different regions of El-Manzala' lake during autumn, 2016

\begin{tabular}{|c|c|c|c|}
\hline $\begin{array}{c}\text { Locations } \\
\text { Parameters }\end{array}$ & El-Boughaz & El-Ganka & Domiette \\
\hline Temperature ${ }^{\circ} \mathrm{C}$ & $30.70 \pm 0.20^{\mathrm{a}}$ & $30.60 \pm 0.30^{\mathrm{a}}$ & $30.50 \pm 0.50^{\mathrm{a}}$ \\
\hline $\mathrm{pH}$ & $8.40 \pm 0.16^{\mathrm{a}}$ & $7.76 \pm 0.04^{b}$ & $8.67 \pm 0.12^{\mathrm{a}}$ \\
\hline Transparency & $28.50 \pm 2.00^{\mathrm{a}}$ & $11.50 \pm 0.50^{\mathrm{c}}$ & $20.20 \pm 1.50^{b}$ \\
\hline $\mathrm{Cm}$ & & & \\
\hline $\begin{array}{l}\text { T. suspended } \\
\text { solid } \mathrm{mg} / \mathrm{l}\end{array}$ & $3.77 \pm 0.17^{\mathrm{b}}$ & $7.85 \pm 0.06^{\mathrm{a}}$ & $5.75 \pm 0.06^{\mathrm{c}}$ \\
\hline $\begin{array}{l}\text { T. dissolved } \\
\text { solids } \mathrm{mg} / \mathrm{l}\end{array}$ & $4.85 \pm 0.21^{\mathrm{a}}$ & $3.22 \pm 0.06^{\mathrm{b}}$ & $2.46 \pm 0.02^{c}$ \\
\hline $\mathrm{DO} \mathrm{mg} / \mathrm{l}$ & $6.80 \pm 0.10^{\mathrm{a}}$ & $2.20 \pm 0.20^{\mathrm{b}}$ & $5.10 \pm 0.20^{\mathrm{a}}$ \\
\hline $\begin{array}{l}\text { T. alkalinity } \\
\mathrm{mg} / \mathrm{l}\end{array}$ & $250.00 \pm 5.80^{\mathrm{a}}$ & $251.70 \pm 6.20^{\mathrm{a}}$ & $261.30 \pm 1.80^{\mathrm{a}}$ \\
\hline $\begin{array}{l}\mathrm{T} . \\
\mathrm{mg} / \mathrm{l}\end{array}$ & $2150 \pm 16.68^{a}$ & $785.00 \pm 15.00^{b}$ & $550.00 \pm 20.00^{c}$ \\
\hline Salinity mg/l & $12.50 \pm 1.10^{\mathrm{a}}$ & $3.60 \pm 0.20^{\mathrm{b}}$ & $2.60 \pm 0.30^{\mathrm{b}}$ \\
\hline $\mathrm{EC} \mathrm{mS/Cm}$ & $8.50 \pm 0.80^{\mathrm{a}}$ & $6.50 \pm 0.40^{\mathrm{b}}$ & $4.77 \pm 0.46^{\mathrm{c}}$ \\
\hline $\begin{array}{l}\text { T. Phosphorus } \\
\mathrm{mg} / \mathrm{l}\end{array}$ & $0.88 \pm 0.03^{b}$ & $1.75 \pm 0.07^{\mathrm{a}}$ & $1.16 \pm 0.02^{\mathrm{ab}}$ \\
\hline $\begin{array}{l}\text { O. Phosphorus } \\
\mathrm{mg} / \mathrm{l}\end{array}$ & $0.32 \pm 0.01^{\mathrm{c}}$ & $0.84 \pm 0.01^{\mathrm{a}}$ & $0.56 \pm 0.03^{b}$ \\
\hline $\mathrm{T}$. nitrogen $\mathrm{mg} / \mathrm{l}$ & $0.56 \pm 0.02^{\mathrm{c}}$ & $2.07 \pm 0.10^{\mathrm{b}}$ & $1.43 \pm 0.02^{\mathrm{a}}$ \\
\hline $\mathrm{NH}_{3} \mathrm{mg} / \mathrm{l}$ & $0.113 \pm 0.005^{\mathrm{b}}$ & $1.023 \pm 0.080^{\mathrm{a}}$ & $0.082 \pm 0.008^{b}$ \\
\hline $\mathrm{NO}_{2} \mathrm{mg} / \mathrm{l}$ & $0.0143 \pm 0.001^{\mathrm{c}}$ & $1.02 \pm 0.06^{\mathrm{a}}$ & $0.047 \pm 0.002^{b}$ \\
\hline $\mathrm{NO}_{3} \mathrm{mg} / \mathrm{l}$ & $0.14 \pm 0.01^{\mathrm{c}}$ & $1.21 \pm 0.10^{\mathrm{a}}$ & $0.49 \pm 0.02^{\mathrm{b}}$ \\
\hline $\begin{array}{l}\text { Chlorophyll a } \\
\mu \mathrm{g} / \mathrm{l}\end{array}$ & $47.90 \pm 2.50^{c}$ & $155.20 \pm 11.60^{\mathrm{a}}$ & $98.14 \pm 5.60^{\mathrm{b}}$ \\
\hline
\end{tabular}

Means with the same litters in the same row are significantly different at $\mathrm{P}<0.05$. $\mathrm{SE}=$ Standard Error

Phosphate plays a role in plant and animal metabolism and thus occurs in their waste products. The highest concentration of total phosphorus (TP) was recorded at El Ganka $(1.75 \pm 0.07 \mathrm{mg} / \mathrm{l})$ while, the lowest was at El-Boughaz $(0.88 \pm 0.03 \mathrm{mg} / \mathrm{l})$ due to the discharging 
of huge amounts of sewage, domestic and agricultural wastes without any treatment, this leading to the increase in the concentration levels of nutrients which were important sources of phosphorus in natural water. El-Ganka regions is closed to Bahr El Bakar, Ramsis and Hadous drains where high rates of drainage water discharge which is the most polluted area. Inorganic nitrogenous compounds ammonium, nitrite and nitrate can be absorbed by phytoplankton living in the aquatic habitat or at least by some species. There is very marked preferential absorption of ammonium. When the organisms suffering from nitrogen deficient and are supplied by nitrogen source, they absorb ammonium and nitrate in the dark and converting them into organic compounds including chlorophyll. Nitrite can't be utilized in the dark (Farouk, 2009). The proportion of nitrogen to phosphorus in phytoplankton is not a fixed ratio. Cells can be deficient in either and the ratio varies with the relative concentration of each in the medium (Farouk, 2009). When phytoplankton or animal tissue is voided by animals, the soluble and particulate nitrogen compounds are broken down by bacteria yielding ammonia.

In concern to total nitrogen $(\mathrm{TN})$, its highest value was recorded at El- Ganka while the lowest one was at El-Boughaz $(2.07 \pm 0.1 \&$ $0.56 \pm 0.02 \mathrm{mg} / \mathrm{l}$, respectively). This may be attributed to the different biological activities. Increased values of TP and TN are related to agricultural wastes and this agrees with the findings of (Farouk, 2009 and Abdo, 2013). Nitrogen could be an important factor controlling algal growth when other nutrients, such as phosphate, are abundant. If phosphate is not abundant it may control algal growth rather than nitrogen (Shaker et al., 2016).

Un-ionized ammonia $\left(\mathrm{NH}_{3}\right)$ had increased values at El-Ganka $(1.023 \pm 0.080 \mathrm{mg} / \mathrm{l})$ followed by Domiette $(0.082 \pm 0.008 \mathrm{mg} / \mathrm{l})$ and then El-Boughaz $(0.113 \pm 0.005 \mathrm{mg} / \mathrm{l})$. The increased values of ammonia $\left(\mathrm{NH}_{3}\right)$ in El-Ganka may be due to the increase in biological activities of aquatic organisms and nitrification due to discharge of agricultural and sewage wastes (Saad $\boldsymbol{e t}$ al., 2011 and Abdel-Satar $\boldsymbol{e t}$ al., 2010). Generally, the high concentration of ammonia (> $1 \mathrm{mg} / \mathrm{l}$ ) has been given as an indicator of organic pollution and it is toxic at concentration over $2.5 \mathrm{mg} / \mathrm{l}$ to aquatic organisms (WHO, 1992). The main source of ammonia nitrogen in the water of feed-base aquaculture ponds is nitrogenous wastes from protein and metabolism 
by aquatic animals and degradation of uneaten feed and feces by microorganisms. Ammonia nitrogen also is introduced to ponds in nitrogen fertilizer such as ammonium sulfate, ammonium phosphate, urea that hydrolyzes into ammonia nitrogen, and in runoff from watershed (Piyajit, 2014).

Nitrite $\left(\mathrm{NO}_{2}\right)$ is an intermediate oxidation state of nitrogen, both in the oxidation of ammonia to nitrate $\left(\mathrm{NO}_{3}\right)$ and in the reduction of nitrate, such oxidation and reduction occur in waste water treatment plants, water distribution systems, and natural water (APHA, 1998). $\mathrm{NO}_{2}$ and $\mathrm{NO}_{3}$ values were high at El-Ganka followed by Domiette and El-Boughaz. The low values of $\mathrm{NO}_{2}$ might be attributed to fast conversion of $\mathrm{NO}_{2}$ by nitrobacteria to $\mathrm{NO}_{3}$ (Tayel, 2007). Ammonia can be converted to nitrite $\left(\mathrm{NO}_{2}\right)$ and nitrate $\left(\mathrm{NO}_{3}\right)$ by bacteria, and then used by aquatic plants and phytoplankton. Nitrate and ammonia are the most common forms of nitrogen in aquatic systems. Nitrate predominates in unpolluted waters.

Chlorophyll gives plants their green color and is produced by microscopic plants called algae in lakes and rivers. There are many human activities that affect chlorophyll in water, such as sewage inputs and destruction of lake. More chlorophyll indicates more algae, which are very important because they form the base of the food chain. If conditions are suitable in the water, algae can grow and cover lakes with green scum or make the water look greener than normal. The highest mean value of chlorophyll a was recorded at ElGanka $(155.2 \pm 11.6 \mu \mathrm{g} / \mathrm{l})$ followed by Domiette $(98.14 \pm 5.6 \mu \mathrm{g} / \mathrm{l})$ and then El-Boughaz $(47.9 \pm 2.5 \mu \mathrm{g} / \mathrm{l})$. These results were suitable with mixed levels of sewage discharge into the lake.

The bacteriological examination of fish environment is important to detect the presence of microorganisms that might constitute health hazard and death of fish. Also, the bacteriological examination of the water source to the fish is very necessary in order to detect the bacteria species being transferred into the fish environments. It can serve as a guide to monitor and protect our fish quality as well as our health.

Data in table 2, show the total bacterial count (TBC), coliform (CF), fecal coliform (E. coli) and Vibrio cholera (V. cholera) in water at different investigated regions of El-Manzala Lake. The highest 
values of total bacterial count at El-Ganka $\left(6.70 \pm 0.88 \times 10^{4} \mathrm{CFU} / \mathrm{ml}\right)$, while in El-Boughaz and Domiette were $5.00 \pm 0.58$ and $3.00 \pm 1.03 \times 10^{4} \mathrm{CFU} / \mathrm{ml}$, respectively. Also the same trend was noticed in the coliform group which was $4.00 \pm 0.21,0.13 \pm 0.03$ and $0.18 \pm 0.04 \times 10^{4} \mathrm{CFU} / \mathrm{ml}$ in El-Ganka, El-Boughaz and Domiette, respectively. Also, fecal coliform and Vibrio cholera recorded the highest numbers in El-Ganka $\left(12.67 \pm 14.55 \times 10^{3}\right.$ and $10.67 \pm 2.34 \times 10^{2}$ $\mathrm{CFU} / \mathrm{ml}$, respectively). This gives direct indicator about increased pollutants levels at El-Ganka location. This conclusion has been supported with the obtained results of many parameters of water quality such as decrease DO, suitable for coliform group which consider facultative anaerobic bacteria. Decrease in $\mathrm{NO}_{2}, \mathrm{NO}_{3}$ and TN explained the nutrient consumed by bacteria and other aquatic life. A comparison of the nutrient levels in different regions also reveal that the TBC increase with the increases of nutrient levels. Sugumar and Anandharaj (2016) revealed positive correlation between TBC and nutrients like phosphates.

Table 2: Average numbers of total bacterial count (TBC), coliform group (CF), fecal coliform (E. coli) and Vibrio cholera (V. cholera) in water samples collected from different regions of El-Manzala' lake during autumn, 2016

\section{Location}

Parameters

$\mathrm{TBC} \times 10^{4}$

(CFU/ml)

$\mathrm{CF} \times 10^{4}(\mathrm{CFU} / \mathrm{ml})$

E. coli $\times 10^{3}$

(CFU/ml)

V. choler $a \times 10^{2}$ $(\mathrm{CFU} / \mathrm{ml})$

\section{El-El-}

Boughaz

$5.00 \pm 0.58$

$6.70 \pm 0.88$

$3.00 \pm 1.03$

EL-Ganka

\section{Domietta}

$0.18 \pm 0.04$

$0.13 \pm 0.03$

$4.00 \pm 0.21$

$0.47 \pm 0.38$

$0.20 \pm 0.0$

$12.67 \pm 14.55$

$0.17 \pm 0.03$

Bacterial investigation of sediment showed in table 3 for the same sites of El-Manzala Lake. The obtained data revealed that the mean numbers of total bacterial count (TBC) was highly increased in ElGanka which was $91 \pm 5.51 \mathrm{CFU} / \mathrm{g}$ while the low numbers recorded in El-Boughaz which was $0.54 \pm .24 \times 10^{5} \mathrm{CFU} / \mathrm{g}$. Also total coliform 
and fecal coliform recorded the high mean numbers in El-Ganka which were $75.66 \pm 1.76 \times 10^{4} \mathrm{CFU} / \mathrm{g}$ and $80.00 \pm 0.00 \times 10^{3} \mathrm{CFU} / \mathrm{g}$, respectively. The low numbers for total coliform $\left(0.57 \pm 0.03 \times 10^{4}\right.$ $\mathrm{CFU} / \mathrm{g}$ ) recorded in El-Boughaz but number of fecal coilform $\left(0.90 \pm 0.58 \times 10^{3} \mathrm{CFU} / \mathrm{g}\right)$ recorded in Domiette. In contrast, vibrio cholera recorded the highest mean numbers in El-Boughaz which was $140.00 \pm 3.06 \times 10^{2} \mathrm{CFU} / \mathrm{g}$, while the lowest mean values were recorded in Domiette $\left(27.00 \pm 0.26 \times 10^{2} \mathrm{CFU} / \mathrm{g}\right)$ and El-Ganka $\left(43.30 \pm 0.71 \times 10^{2} \mathrm{CFU} / \mathrm{g}\right)$. The increase in Vibrio cholera at ElBoughaz may be due to the increase of salinity as confirmed in this study and found previously by Fishar (1999).

Table 3: Average numbers of total bacterial count (TBC), coliform group (CF), fecal coliform (E. coli) and Vibrio cholera (V. cholera) in sediment samples collected from different regions of El-Manzala' lake during autumn, 2016

\begin{tabular}{lccc}
\hline \multicolumn{1}{c}{$\begin{array}{c}\text { Location } \\
\text { Parameters }\end{array}$} & El-El-Boughaz & EL-Ganka & Domietta \\
\hline $\begin{array}{l}\mathrm{TBC} \times 10^{5} \\
(\mathrm{CFU} / \mathrm{g})\end{array}$ & $0.54 \pm .24$ & $91.00 \pm 5.51$ & $7.07 \pm 0.41$ \\
$\mathrm{CF} \times 10^{4}(\mathrm{CFU} / \mathrm{g})$ & $0.57 \pm 0.03$ & $75.66 \pm 1.76$ & $10.00 \pm 0.00$ \\
$\begin{array}{l}\mathrm{E} \text { coli } \times 10^{3} \\
(\mathrm{CFU} / \mathrm{g})\end{array}$ & $1.93 \pm 2.91$ & $80.00 \pm 0.00$ & $0.90 \pm 0.58$ \\
V. cholera $\times 10^{2}$ & $140.00 \pm 3.06$ & $43.3 \pm 0.71$ & $27.00 \pm 0.26$ \\
$(\mathrm{CFU} / \mathrm{g})$ & & & \\
\hline
\end{tabular}

The flow of water into the lake comes mainly from two drains. The sewage Bahr El-Bakar drain discharges highest pollutant load at Bashtir location. The Bahr Hados drain feeds the lake with agriculture waste waters at the area of El-Ganka. So, Bashtir and El-Ganka zones represent two different reservoirs of bacterial communities affected by anthropogenic pollution. El-Shabrawy and Germoush (2014) stated that, Manzala Lake is a eutrophic coastal lake that has been flooded by excess agriculture drainage over the last 30 years, changing its ecological status. It has undergone substantial changes recently due to regulation of freshwater inflows, land reclamation and increasing discharges of pollutants. This is particularly associated with polluted drains flowing into the lake. Increases in pollutant concentrations can be attributed to increased use of fertilizers 
combined with an expanding population served by sewers, improved living standards and increased industrial production. Pollutant enrichment has resulted in declining water quality and eutrophication, especially in the southern parts of Lake (Rasmussen et al., 2009).

Data in table (4) indicted the variation of bacterial load in muscle, skin and gills of tilapia fish; Oreochromis niloticus and Catfish; Clarias gariepinus. The lowest numbers were recorded in muscles and the highest were in gills followed by the skin in all bacterial examinations for both fish species.

Total bacterial count and coliform in muscle of tilapia $\left(3.33 \pm 0.33 \times 10^{3}\right.$ and $0.97 \pm 0.09 \times 10^{3} \mathrm{CFU} / \mathrm{g}$, respectively) was lower than those recorded in catfish $\left(14.33 \pm 1.20 \times 10^{3}\right.$ and $1.50 \pm 0.58 \times 10^{3}$ $\mathrm{CFU} / \mathrm{g}$, respectively). This may be due to that muscle of catfish is not protected, so easily microbes penetrate it. Also, catfish always prefer staying in mud and become more exposed to high pollutant in sediment than water. While fecal coliform and vibrio cholera not detected in muscle of the two fish species. These results agree with Hamed et al. (2013).

Total bacterial count of tilapia skin $(9.77 \pm 5.37 \times 105 \mathrm{CFU} / \mathrm{cm})$ was higher than that of catfish $(7.53 \pm 0.29 \times 105 \mathrm{CFU} / \mathrm{cm})$, also coliform group was higher in tilapia skin $\left(2.5 \pm 0.03 \times 10^{5} \mathrm{CFU} / \mathrm{cm}\right)$ than in catfish $\left(0.63 \pm 0.09 \times 10^{5} \mathrm{CFU} / \mathrm{cm}\right)$. In contrast fecal coliform $(E$. coli) was higher in catfish skin $\left(8.56 \pm 0.79 \times 10^{2} \mathrm{CFU} / \mathrm{cm}\right)$ than in tilapia skin $\left(2.33 \pm 0.33 \times 10^{2} \mathrm{CFU} / \mathrm{cm}\right)$ due to staying catfish long time in mud. With respect to $V$. cholera, no significant variations were noticed in skin of both fish species.

Gills of tilapia recorded higher numbers of TBC, coliform and fecal coliform $\left(80.00 \pm 10.03 \times 10^{5}, \quad 17.00 \pm 1.50 \times 10^{5} \quad\right.$ and $41.00 \pm 2.084 \times 10^{5} \mathrm{CFU} / \mathrm{g}$, respectively) than in gills of catfish $\left(28.33 \pm 1.77 \times 10^{5}, \quad 15.67 \pm 1.86 \times 10^{5}\right.$ and $15.33 \pm 0.33 \times 10^{3} \mathrm{CFU} / \mathrm{g}$, respectively). These results may be due to that gills of catfish anatomically are more protected than gills of tilapia. 
Table 4: Average numbers of total bacterial count (TBC), coliform group (CF), fecal coliform (E. coli) and Vibrio cholera $(V$. cholera) in muscles, skin and gills of $O$. niloticus and $C$. gariepinus from El-Manzala' lake during autumn, 2016

\begin{tabular}{llcccc}
\hline Organs & Fish species & TBC & CF & E. coli & V. cholera \\
\hline \multirow{2}{*}{ Muscle (CFU/g) } & O. niloticus & $3.33 \pm 0.33 \times 10^{3}$ & $0.97 \pm 0.09 \times 10^{3}$ & $0.00 \pm 0.00$ & $0.00 \pm 0.00$ \\
& C. gariepinus & $14.33 \pm 1.20 \times 10^{3}$ & $1.50 \pm 0.58 \times 10^{3}$ & $0.00 \pm 0.00$ & $0.00 \pm 0.00$ \\
& O. niloticus & $9.77 \pm 5.37 \times 10^{5}$ & $2.50 \pm 0.03 \times 10^{5}$ & $2.33 \pm 0.33 \times 10^{2}$ & $0.30 \pm 0.06 \times 10^{2}$ \\
\multirow{2}{*}{ Skin $(\mathrm{CFU} / \mathrm{cm})$} & C. gariepinus & $7.53 \pm 0.29 \times 10^{5}$ & $0.63 \pm 0.09 \times 10^{5}$ & $8.56 \pm 0.79 \times 10^{2}$ & $0.43 \pm 0.03 \times 10^{2}$ \\
& O. niloticus & $80.00 \pm 10.03 \times 10^{5}$ & $17.00 \pm 1.50 \times 10^{5}$ & $41.00 \pm 2.084 \times 10^{3}$ & $60.33 \pm 1.45 \times 10^{2}$ \\
\multirow{2}{*}{ Gills $(\mathrm{CFU} / \mathrm{g})$} & C. gariepinus & $28.33 \pm 1.77 \times 10^{5}$ & $15.67 \pm 1.86 \times 10^{5}$ & $15.33 \pm 0.33 \times 10^{3}$ & $65.33 \pm 2.89 \times 10^{2}$ \\
\hline
\end{tabular}


Interpretation of the detected bacterial indicators in the lake waters were done according to the European Commission (EC) Guide Standard (EC, 1997), which meet with the Egyptian Guide Standard (Ministry of Health, Egypt, 1996). They accept the guide values of the investigated bacteria up to $50 \mathrm{CFU} / \mathrm{ml}$ of marine water for coliforms and $1 \mathrm{CFU} / \mathrm{ml}$ for fecal coliforms (E. coli). The present findings revealed values exceed the permissible values mentioned by EC, 1997 and Ministry of Health, Egypt, 1996.

Therefore, in order to keep the water quality of Lake El-Manzala in the safe side to prevent the damage of fish environment, hard works should be done to reduce the discharging of domestic, industrial and agricultural drainage into the lake.

\section{References}

Abbassy, M. S.; H. Z. Ibrahim, and H. M. Abdel-Kader, (2003): 'Persistent organochlorine pollutants in the aquatic ecosystem of Lake Manzala, Egypt', Bull Environ. Contam. Toxicol. 70:11581164.

Abdel-Satar, A. M.; Goher, M. E. and M. F. Sayed, (2010): Recent environmental changes in water and sediment quality of Lake Qaroun, Egypt. J. Fish and Aquat. Sci., 5(2): 56-69.

Abdo, M.H. (2013): Physico-Chemical Studies on the Pollutants Effect in the Aquatic Environment of Rosetta Branch River Nile, Egypt. Life Science Journal, 10: 493-501.

APHA (American Puplic Health Assocition), (1992): Standard Methods for the Examination of water and waste, $18^{\text {th }}$ ed., American public Health Association, washing ton.

APHA (American Puplic Health Assocition), (1995): Standard Methods for the Examination of water and waste, American public Health Association. New York, 1193 pp.

APHA (American Puplic Health Assocition), (1998): Standard Methods for the Examination of water and wastewater, 20th Edition. D. C, pp.110-161.

Ali, M. H. H. (2008): Assessment of some water quality characteristics and determination of some heavy metals in Lake Manzala, Egypt. Egypt J Aquat Biol Fish, 12(2):133-154 
Bailey, N. T. (1981): Statistical Methods in Biology. $2^{\text {nd }}$ ed. (Biological Science Texts).

Baker, K. H. and D. S. Herson, (1999): Detection and occurrence of indicator organisms and pathogens. Water Environ. Res. 37: 909913.

Begum, A.; M. d. N. Amin; A. Kaneco and K. Ohta, (2005): Selected elemental composition of the muscle tissue of three species of fish, Tilapia nilotica, Cirrhina mrigala and Clarias batrachus, from the fresh water Dhanmondi Lake in Bangladesh. Food. Chem., 93: 439 - 443.

Bishai, H. M. and S. F. Yosef, (1977): Some aspects on the hydrography, physicochemical, characteristics and fisheries of lake Manzala . Bulletin of the Institute of Oceanography and Fisheries 7(1): 32-58.

Boyd, C. E. and C. S. Tucker, (1992): Water Quality and Pond Soil Analysis for aquaculture. Alabama Agricultural Experimental Station. Auburn Univ. Pp.183.

Delince, G. (1992): The ecology of the fish pond ecosystem with special reference to Africa. Text book, kluwer Academic Publishers, $230 \mathrm{pp}$.

DRI (Drainage Research Institute), (2010): Real-time water quality monitoring along the Nile River. Technical report of project of an environmental security and water resources management system using real-time water quality warning. El Kanater, Egypt. 96 pp.

EC (European Commission), (1997): Quality of bathing water; Document EUR 18166, European Commission, Brussels.

El-Asmar, H. M. and M. E. Hereher, (2011): "Change detection of the coastal zone east of the Nile Delta using remote sensing," J. Environmental Earth Sciences, 62(4): 769-777, Feb. 2011. Doi.

El-Badry, A. E. A, (2016): Distribution of Heavy Metals in Contaminated Water and Bottom Deposits of Manzala Lake, Egypt. J. Environ Anal Toxicol 6:344. doi:10.4172/21610525.1000344

El-Bokhty, E. E. B. (2010): Fisheries management of Oreochromis niloticus and Oreochromis aureus caught by Trammel Nets and Basket Traps in Lake Manzalah, Egypt .World Journal of Fish and Marine Sciences, 2(1): 51-58. 
Elewa, A. A.; E. A. Saad; M. B. Shehata and M. H. Ghallab, (2007): Studies on the effect of drain effluents on the water quality of Lake Manzala, Egypt. J. Aquat. Biol. \& Fish., 11(2): 65-78.

El-Shabrawy, G. M. and M. O. A. Germoush, (2014): Seasonal changes and abundance of rotifers in a shallow Manzalah lake (Egypt), J. Ecohydrology \& Hydrobiology, vol. 14(3): 243-252. http://dx.doi.org/10.1016/j.ecohyd.2014.06.001

EPA (Environmental Protection Agency), (1999): Guidance manual for compliance with the interim enhanced surface water treatment rule. United States, Office of Water (4607) publishing, EPA-815-R-99-010; April 1999. 201pp.

Farouk, A. E. A. (2009): Some studies on water pollution of Manzala Lake by heavy metals and others and effect of these on stock assessment of fish. M.Sc. Thesis. Faculty of Science. AlAzhar University.

Fathi A. A; H. M. Abdelzaher; R. Flower; M. Ramdani and M. Kraiem, (2001): Phytoplankton communities in North African wetland lakes: The CASSARINA project. Aquat. Ecol 2001; 35:303-318.

Fong, T. T.; D. W. Griffin, and E. K. Lipp, (2005): Molecular assays for targeting human and bovine enteric viruses in coastal waters and their application for library independent source tracking. Appl. Environ. Microbiol. 71: 2070-2078.

Fishar, M. R. A., (1999): "Distribution and abundance of benthic assemblages in El-Gamil basin (Lake Manzalah, Egypt)," Bull. Nat. Inst. Oceanogr. \& Fish., ARE., vol. 25:151-166, 1999. Available: $\quad$ http://www.nodc-egypt.org/en/2013-09-04-11-30Journal of Natural Resources and Development 2015; 05:76- 87 DOI number: 10.5027/jnrd.v5i0.11 51/144-volume-25-1999

Frederickson, J. K.; J. M. Zachara; D. L. Balkwill; D. Kennedy; S. W. Li; H. M. Kostandarithes; M. J. Daly; M. F. Romine and F. J. Brockman, (2004): Geomicrobiology of high level nuclear waste contaminated vadose sediments at the Hanford Site, Washington State. Appl. Environ. Microbiol. 70:4230-4241.

Frihy, O.; K. Dewidar; S. Nasr and M. El Raey, (1998): Change detection of the northern Nile Delta of Egypt: shoreline changes, Spit evolution, margin changes of Manzala lagoon and its islands. Int. J. Remote Sensing, 19: 1901-1912. 
Hamed Y. A.; T. S. Abdelmoneim; M. H. ElKiki; M. A. Hassan and R. Berndtsson, (2013): Assessment of Heavy Metals Pollution and Microbial Contamination in Water, Sediments and Fish of Lake Manzala, Egypt Life Science Journal, 10(1): 86-99.

Jamabo, N. A., (2008): Ecology of Tympanotonus fuscatus (Linnaeus, 1758) in the Mangrove Swamps of the Upper Bonny River, Niger Delta, Nigeria. Ph.D. Thesis, Rivers State University of Science and Technology, Port Harcourt, Nigeria 2008, 231.

Koussa, A. A. (2000): Effect of Industrial and Organic Pollution on Potential Productivity and Fish Stock of Lake Mariut, Northern Egypt with a predictive study of that effect on the Lake. Ph.D. Thesis. Fac. Sci. Ain Shams Univ. Egypt.

Margesin, R. and F. Schinner, (2005): Manual for soil analysis monitoring and assessing soil bioremediation. Soil Biology, vol. 5. Springer-Verlag, Berlin, Heidelberg.

Moussa, S. M. S. (2004): Impact of Inorganic Pollutants on Aquatic Environment and Fish Performance in Lake Borollus. Ph. D. Thesis, Inst. of Environment Stud. and Res., Biol. \& Phys. Dep., Ain hams Univ., Egypt.

Ministry of Health, Egypt, (1996): Microbiological Standards of the Egyptian Recreational Waters. Report No. 64

Piyajit, P., (2014): Effect of ammonia nitrogen on production and Haemolymph of pacific white shrimp (Litopenaeus vannamei) cultured in low salinity ponds in Green county, Alabama. Thesis, M.Sc. Faclty of Agriculture. Auburan Univ.

Rasmussen, E. K; O. S. Petersen; J. R. Thompson; R. J. Flower and M. H. Ahmed, (2009): Hydrodynamic-ecological model analyses of the water quality of Lake Manzala (Nile Delta, Northern Egypt)," J. Hydrobiol., 622(1):195-220.

Ruangpan, L. and T. Kitao, (1991): Vibrio bacteria isolated from black tiger shrimp, Penaeus monodon Fabricius. J. Fish Dis. 14: 383-388.

Saad, S. M.; A. E. El-Deeb,; S. I. Tayel, and N. A. M. Ahmed, (2011): Haematological and histopathological studies on Clarias gariepinus in relation to water quality along Rosetta branch, River Nile, Egypt, J. Exp. Biol. (Zool.), 7(2):223-233. 
Shaker, I. M., (2006): Water hyacinth as a biological treatment for sewage wastewater in aquaculture earthen ponds. Egyptian Journal of Aquatic Biology and Fisheries, 10:1-20.

Shaker, I. M.; M. H. Ahmed and A. M. A. Soliman, (2016): Environmental impacts of managements on water quality, plankton abundance and productions of tilapia and mullet in earthen ponds. Abbassa Inter. J. Aqua., 9(2):

Shaker, I. M. and M. Abdel-Aal, (2006): Growth Performance of fish reared under different densities in semi- intensive and extensive earthen ponds. Egypt. J. Aquat. Biol. \& Fish., 10(4): 109-127.

Sugumar, R. and B. Anandharaj, (2016): Assessment of Bacterial Load in the Fresh Water Lake System of Tamil Nadu International Journal of Current Microbiology and Applied Sciences ISSN: 2319-7706 Vol. 5(6): 236-246

Tayel, S. I. (2003): Histopathological, biochemical and hematological studies on Tilapia zillii and Claries gariepinus in relation to water quality criteria at different localities in Delta Barrage. Ph.D. Thesis, Fac. Sci., Benha branch, Zagazig Univ.

Tayel, S. I.; A. M. Yacoub and S. A. Mahmoud, (2008): Histopathological and haematological responses to freshwater pollution in the Nile catfish Clarias gariepinus. J. Egypt. Acad. Soc. Environ. Develop. 9(4): 43- 60.

Wetzel R. G., (1983): Limnology, $2^{\text {nd }}$ ed. Saunders College Publishing, Philadelphia, PA, 1983.

WHO (World Health Organization), (1992): International program on chemical safety, Environmental Health Criteria, 6: 325-329. 


\section{تقييم بعض عوامل جودة المياه والتلوث البكتيري في المياه والتربة وبعض

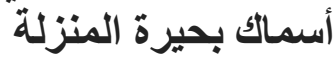$$
\text { إيمان عطية عبد السميع عبد الحميد }
$$

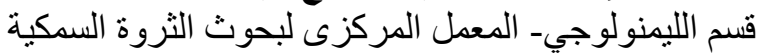

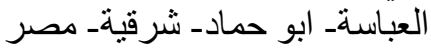$$
\text { الملخص العربى }
$$

للماء دورا حيويا في حسن سير النظام البيئي وأساسي لحياة الأسماك. أجريت الدر اسة في

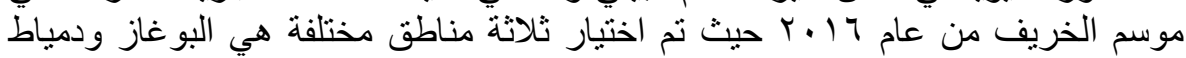

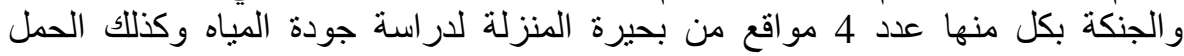

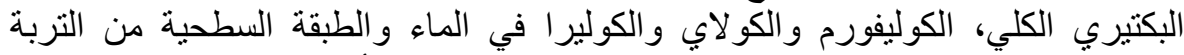

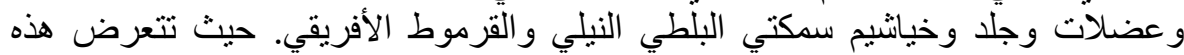

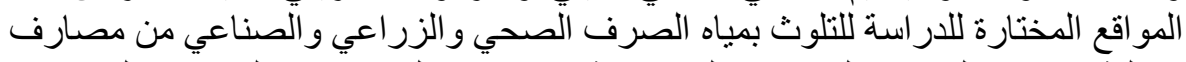

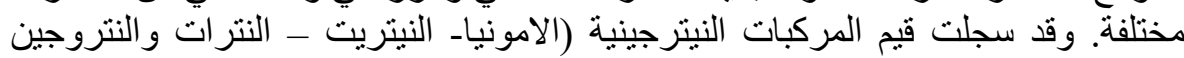
الكلى) و الفوسفور الكلى و الكلوروفيل ازيادة معنوية في منطقة الجنكة ويليها منطقة دمياط

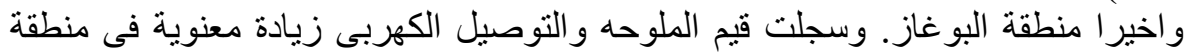
البوغاز عن باقى المناطق نظر اللتبادل المائى بين البحيرة واله والبحر المتوسط.

أما العدد الكلي للبكتيريا، مجموعة بكتريا القولون والكولاي و الكولير ا فقد سجلت قيما أعلى الكى الكي

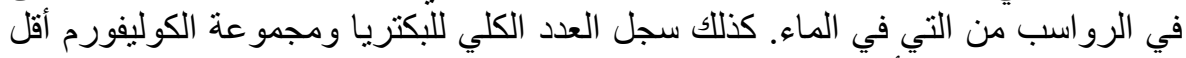

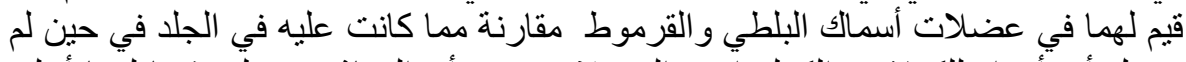

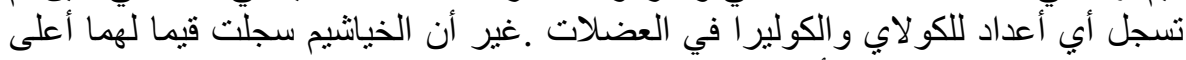

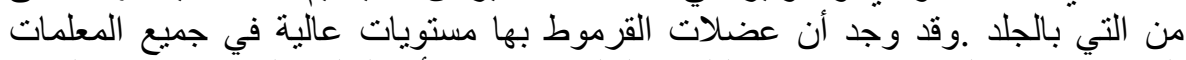
البكتيرية عن التي في عضلات البلطي النيلي. في حين أن الجلد والخيأشيم كانت النتائج عكسية.

تشير هذه الدراسة إلى ضرورة الإهتمام بنوعية المياه التي تصب في بحيرة المنزلة و العمل


بالبحيرة لتكون جيدة لأغر اض ثربية الأحياء المائية والأسماك حفاظة على على البيئة المائية الئية وصحة الإنسان. 